\title{
Prediction of the preeclampsia: a view of biochemical markers
}

Mehmet Sühha Bostancı ${ }^{1}$, Merih Bayram ${ }^{2}$, Arif Serhan Cevrioğlu ${ }^{1}$, Selçuk Özden ${ }^{1}$, Nermin Akdemir ${ }^{1}$, Sedat Umur ${ }^{1}$

1 Sakarya University, Faculty of Medicine Department of Obsterics and Gynecology, Sakarya, Turkey

2 Gazi University, Faculty of Medicine Department of Obsterics and Gynecology, Ankara, Turkey

\section{Abstract}

Preeclampsia is a diverse, multiorgan group of related disease processes that occurs in up to $5 \%-8 \%$ of pregnancies after 20 weeks' gestation and it is one of the leading causes of maternal and fetal morbidity and mortality. Many molecular mechanisms are contributed to the pathogenesis of preeclampsia. Although it is unknown whether the mechanisms act independently or have synergistic effects. This review describes review of primary papers investigating blood based biomarker such as PAP-A, Inhibin A, sFlt1, and PP13 in general and first trimester biochemical markers and combinations of them specifically for preeclampsia.

\section{Keywords}

Preeclampsia; Biochemical markers; Pregnancy-associated placental protein A 


\section{Introduction}

Hypertensive disorders of pregnancy are important causes of maternal and fetal mortality and morbidity. Along with infection and hemorrhage, it stands among the three most common causes of maternal mortality. The reported rate of hypertension with pregnancy is $5-10 \%$ of all pregnancies [1]. Major risk factors for preeclampsia (PE) include nulliparity, multifetal gestations, previous history of preeclampsia, obesity, diabetes mellitus, vascular and connective tissue disorders like systemic lupus erythematosus and antiphospolipid antibodies, age $>35$ years at first pregnancy, smoking. Preeclampsia is considered a disease of nulliparous women, as it is twice as common in primigravidas as it is in women who have previously given birth [2]. PE is characterized by a complex pathophysiology and heterogeneous clinical and laboratory findings. The relation between these risk factors and preeclampsia is poorly understood. Most theories on the etiology of preeclampsia suggest that the disease is a cascade triggered by combination of abnormal maternal inflammatory response, endothelial cell activation/damage with deranged hemodynamic milieu, and deranged immunity [3,4].

The current theory of the pathogenesis of PE as reviewed by Christopher Redman and Ian Sargent is thought to occur as a 2-stage process with poor placentation in the first half of pregnancy resulting in the maternal response in the second half of pregnancy $[5,6]$.

Increasing evidence suggests that an excessive maternal systemic inflammatory response to pregnancy with activation of both the innate and adaptive arms of the immune system is involved in the pathogenesis of the disease [7]. After conception, regulatory $\mathrm{T}$ cells, interacting with indoleamine 2,3-dioxygenase, together with decidual NK cell recognition of fetal HLA-C on extravillous trophoblast may facilitate placental growth by immunoregulation. Complete failure of this mechanism would cause miscarriage, while partial failure would cause poor placentation and dysfunctional uteroplacental perfusion [8]. Bayram et al. found that the patient with severe preeclampsia have higher values of IL- 6 and IL-1 $\beta$ when compared to the normotensive ones [9]. Increased level of IL-6 and TNF- $\alpha$ may play a role of triggering factors for preeclampsia. Uterine NK cells, the major lymphocytes present in the decidua during pregnancy, have the ability to produce and be regulated by IL-10 [10]. Kalkunte et al. showed that reduced production of IL-10 may contribute to poor placentation and induction of vasoactive antiangiogenic factors. Curiously, evaluation of placental tissue and serum samples from PE has suggested reduced IL-10 production [11].

Currently, no definitive treatment or effective prophylaxis for preeclampsia is available. Delivery and consequent removal of the placenta is the "treatment", often with a premature baby as the result.

The National High Blood Pressure Education Program of the NHLBI classifies hypertensive disorders of pregnancy into following categories: gestational hypertension, chronic hypertension, preeclampsia, and preeclampsia superimposed on preexisting hypertension [5].

According to the International Society for the Study of Hypertension in Pregnancy (ISSHP), PE can be defined as de novo hypertension occurring after 20 weeks of pregnancy together with proteinurea. Hypertension is defined as a systolic blood pressure $\geq 140 \mathrm{mmHg}$ and/or a diastolic blood pressure $\geq$ $90 \mathrm{mmHg}$ measured at two occasions with at least $4 \mathrm{~h}$ in between. Proteinurea is defined as $\geq 300 \mathrm{mg}$ per day in at least 2 random urine specimens that were collected at least $\geq 4$ hours apart (but within a 7-day interval) or $0.3 \mathrm{~g}$ in a 24 -hour period [6].

In the recent years, facilities for the researches have been made more widely available. Genomics, proteomics and metabolomics modalities are popular and possible to evaluate. In search of the etiology of PE, several new pathways and factors have been described by using these techniques. So that the researchers were able to work on the etiology of PE may affect the new pathways and markers. Aim of these researches is to describe the etiological factors measurable in the maternal blood and their evaluation as biochemical markers for prediction and diagnosis of PE. The main of these markers are about endothelial dysfunction, metabolic status, oxidative stress, placenta-derived factors, hemolysis 
and inflammatory markers. Also serum/plasma markers for renal dysfunction are important about the etiology of PE.

The ultimate goal of a preeclampsia biomarkers would be that appropriate improving maternal health situation and detection of the conditions which affect development of the fetus. As a result of definition these markers could possibly improve our understanding of the pathophysiology in preeclampsia. By the way identification of new therapeutic targets, as many of the markers probably contribute to the pathophysiology can help to find appropriate treatment modalities. Also understanding the exact pathophysiology of PE may allow clinician to prevent disease before the symptoms occur.

Few biochemical markers have been proven specific and sensitive as single markers to predict and/or diagnose PE. Beside these biochemical markers clinical measurements such as Doppler ultrasound is important for estimation of the PE. In this review we describe biochemical markers suggested for both prediction and diagnosis of PE.

\section{Biochemical markers}

\section{Pregnancy-associated placental protein A}

Pregnancy-associated placental protein A (PAPP-A) is a large, highly glycosylated protein synthesized in the placenta by the developing trophoblast. The study of PAPP-A as a biochemical marker in pregnancy has been pursued for almost 30 years [12]. PAPP-A has been used in combination with $\beta$-human chorionic gonadotropin ( $\beta$-hCG) and nuchal translucency thickness. Aim of using these three markers is detection of Down syndrome at $11+0$ to $13+6$ weeks of gestation [13].

PAPP-A has been evaluated as a predictive and diagnostic biochemical marker for PE. But the screening performance is extremely low when used as a single biochemical marker and the predictive rate is only about 10-20\% [14]. Several studies denoted low first or second trimester serum PAPP-A value is predictive and diagnostic biochemical marker of preeclampsia [14-23]. First trimester serum PAPPA is low also prior to other pregnancy complications, such as in pregnancies developing fetal growth restriction, spontaneous miscarriage placental abruption, preterm birth and stillbirth and gestational diabetes $[15,16,20,23]$. Because of these other complication of the pregnancy usefulness of PAPP-A as a preeclampsia biomarker is restricted (Table I). D'Anna et al. showed that PAPP-A is not a predictive marker for patients with onset of preeclampsia after 34 week of the gestation [21]. When the combina-

\begin{tabular}{|lccl|}
\hline \multicolumn{1}{|c}{ Reference } & Pz (n.) & Gestational week & \multicolumn{1}{c|}{ Results } \\
Ong [15] & 5,584 & $10-14$ & Low PAPP-A prediction of PE, PIH, miscarriage, FGR \\
Smith [16] & 8,839 & $8-14$ & Low PAPP-A prediction of PE; FGR, premature birth, stillbirth \\
Bersinger [17] & 118 & $17,25,33$ & Low PAPP-A at week 17 predicts PE also FGR \\
Dugoff [20] & 33,395 & $10-14$ & $\begin{array}{l}\text { Low PAPP-A predicts adverse pregnancy outcome, included PE and } \\
\text { PIH, fetal loss, SGA, placental abruption, preterm premature rupture of } \\
\text { membranes. Low sensitivity and PPV }\end{array}$ \\
& & Low PAPP-A not predictive of PE \\
\hline D'Anna [21] & 2,432 & $9-11$ & L
\end{tabular}

Table I. Biochemical prediction of Pregnancy-associated Protein A (PAPP-A) as marker of preeclampsia

FGR = fetal growth restriction; PE = preeclampsia; PIH = Pregnancy induced hypertension; PPV = positive predictive value; SGA = small for gestational age I siRNA (small interfering RNA) 
tion of PAPP-A with Doppler ultrasound is used, PAPP-A became a powerful predictive biochemical marker of PE with prediction rates of $70 \%$ at false positive rates of 5\% [18]. Nonetheless the sensitivity of PAPP-A is still too low to provide useful screening biomarker for preeclampsia. As the result of these PAPP-A might be a better marker for fetal growth restriction than preeclampsia [22].

\section{Inhibin $\mathrm{A}$ and activin $\mathrm{A}$}

Inhibin A and activin A are glycoprotein hormones and members of the TGF (transforming growth factor) $-\beta$ family. The placenta is the primary source of inhibin $A$ and activin A during pregnancy. The concentrations of these circulating proteins increase with the last trimester of uncomplicated pregnancies. Muttukrishna et al. found that maternal serum concentrations of inhibin A and activin A are more elevated in women with preeclampsia as compared to normotensive control women [23]. Some authors have confirmed that elevated inhibin A/activin A levels in first trimester [24,25] or in second trimester [26-30] could predict preeclampsia (Table II). Spence et al. found that elevated inhibin A and activin A levels combined with uterine artery doppler measurement become a more accurate predictive values in second trimester [30].

\section{Placental protein 13}

Placental protein 13 (PP13) is a member of the galectin family and is a $32-\mathrm{kDa}$ dimer protein that is produced by the trophoblast cells in placenta [31,32]. The real function of PP13 is still not clearly understood, but it is involved in placental implantation and maternal vascular remodeling [31]. Several studies have shown lowered serum level of PP13 in the first trimester in pregnancies that subsequently developed PE (Table III). As a first trimester screening marker for PE, PP13 shows different prediction rates in different studies. In two different cohort studies, PP13 levels were determined at $11+0$ to $13+$ 6 weeks of gestation [33,34]. At false positive rates of $5 \%$ and $10 \%$ they found detection rates of $37.5 \%$ and $69 \%$ respectively, using PP13 as a single biochemical marker. It seems that a combination of PP13 and uterine artery Doppler PI is a better prediction test for preeclampsia than either test alone, either if performed simultaneously in gestational week 11-14. When combining serum screening with Doppler ultrasound pulsatility index (PI), the prediction rate increased to $71 \%$ at a false positive rate of $10 \%$ [34]. Nicolaides et al. found that PP13 is a biochemical marker for early onset PE in gestational week 11-14 [35]. At a false positive rate of $10 \%, \mathrm{PP} 13$ showed a prediction rate of $80 \%$ as a single biochemical marker. In combination with Doppler ultrasound PI measurements, the prediction rate increased to $90 \%$ [35]. PP13 has also been used in combination with PAPP-A. Stamatopoulou et al. studied PP13 and PAPP-A at $11+0$ to $13+6$ weeks of gestation in hypertensive pregnancies and pregnancies complicated by SGA. They found that PAPP-A was significantly lower in SGA and in hypertensive disorders but interestingly, the levels of PP13 did not differ between the cases and the controls [36].

\begin{tabular}{|c|c|c|c|}
\hline Reference & $\mathrm{Pz}$ (n.) & Gestational week & Results \\
\hline Roes [25] & 36 & $6-15$ & Elevated inhibin-A predicts PE. Sensitivity $(32 \%)$ \\
\hline Diesch [26] & 15 & $19-24$ & Second trimester elevated activin $\mathrm{A}$ in a high-risk population predicts $\mathrm{PE}$ \\
\hline Zwahlen [27] & 52 & $11-14$ & Increased activin $A$ and inhibin $A$ predicts $P E$ \\
\hline Muttukrishna [28] & 1,596 & $15-19$ & $\begin{array}{l}\text { Elevated inhibin } \mathrm{A} \text { and activin } \mathrm{A} \text { predicted } \mathrm{PE} \text {. Activin } \mathrm{A} \text { is more } \\
\text { predictive than inhibin } \mathrm{A}\end{array}$ \\
\hline Spencer [30] & 24 & $22-25$ & $\begin{array}{l}\text { UA Doppler in addition to elevated activin A and inhibin A gave better } \\
\text { prediction for PE than either markers alone }\end{array}$ \\
\hline
\end{tabular}

Table II. Biochemical prediction of Inhibin A and Activin A as marker of preeclampsia $\mathrm{PE}=$ preclampsia, $\mathrm{UA}=$ uterine artery 


\begin{tabular}{|lccl|}
\hline \multicolumn{1}{|c}{ Reference } & Pz (n.) & Gestational week & \multicolumn{1}{c|}{ Results } \\
\hline Akolekar [33] & 48 & $11-14$ & PP13 is predictive for subsequent development of early PE \\
Khalil [34] & 42 & $11-14$ & $\begin{array}{l}\text { Combination of first-trimester PP13, uterine artery PI analysis is } \\
\text { promising for the prediction of PE }\end{array}$ \\
\hline Nicolaides [35] & 423 & $11-14$ & $\begin{array}{l}\text { Low PP13 predicts PE. Uterine artery PI improves detection rate of } \\
\text { early onset PE: 90\% detection rate }\end{array}$ \\
Stamatopoulou [36] & 452 & $11-14$ & PP13 did not differ between the cases and the controls \\
\hline
\end{tabular}

Table III. Biochemical prediction of Placental protein 13 as marker of preeclampsia

$\mathrm{PE}=$ preeclampsia; $\mathrm{PI}=$ pulsatility index; $\mathrm{PP} 13$ = placental protein $13 ; \mathrm{UA}=$ uterine artery

\section{Vascular endothelial growth factor}

Circulating free vascular endothelial growth factor (VEGF) is very low in pregnancy. The main problem to use VEGF to demonstrate as a marker is hard to detect it with the Elisa kits. Polliotti et al. demonstrated that a low VEGF was predictive of subsequent preeclampsia [37]. Levine et al. found that free VEGF was lower in women developing preeclampsia as compared to women remaining normotensive only 5 weeks before disease development [38].

\section{Placental growth factor}

Placental growth factor (PlGF) is a member of the VEGF family which secreted by trophoblast cells of placenta. PIGF has a proangiogenic function at the site of the placenta. Preeclampsia occurs as the result of impaired placentation. Subsequent ischemic situation occurs because of an increased secretion of antiangiogenic factors such as soluble Fms-like tyrosine kinase-1 (sFlt-1) and soluble endoglin (sEng) in the maternal circulation. By the way this situation leads to a course of antagonizing the angiogenic factors such as PlGF. Some studies have found that low PlGF is a good predictive factor in first trimester for preeclampsia [39-43], while other studies showed no predictive value for PlGF in first trimester [44-47]. Most studies have found that low PlGF in the second trimester predicts later occurrence of preeclampsia [47-54]. The ratio of the PlGF/sFlt-1 is well described and this new value has shown as an appropriate biochemical marker for prediction of PE [55]. Several studies have shown the predictive power of PlGF/sFlt-1 ratio from the second trimester (Table IV).

\begin{tabular}{|c|c|c|c|}
\hline Reference & $\mathrm{Pz}$ (n.) & Gestational week & Results \\
\hline Tidwell [39] & 39 & $\begin{array}{l}5-15 \\
16-20 \\
26-30\end{array}$ & $\begin{array}{l}\text { Low PIGF week all trimesters predict severe PE. Low PIGF week 5-15 (but } \\
\text { not later in pregnancy) predicts mild PE }\end{array}$ \\
\hline Thadhani [40] & 80 & $7-12$ & $1^{\text {st }}$ trimester low PIGF predicts $\mathrm{PE}$, not SGA \\
\hline Taylor [44] & 1,496 & Full term & $\begin{array}{l}\text { PIGfF }<14 \text { th week: does not predict PE/SGA. Low PIGF predicts PE + SGA } \\
\text { from week 15-19. Low PIGF predicts PE as well as PE + SGA from week } \\
21-25\end{array}$ \\
\hline Tjoa [47] & 72 & $11-21$ & PIGF week 14-17 does not predict PE. Low PIGF week 17-21 predicts PE \\
\hline Espinazo [52] & 3,348 & $22-26$ & $2^{\text {nd }}$ trimester low PLGF predicts PE (in women with abnormal UA Doppler) \\
\hline
\end{tabular}

Table IV. Biochemical prediction of Placental growth factor as marker of preeclampsia

$\mathrm{PE}=$ preeclampsia; $\mathrm{PIGF}=$ placental growth factor; SGA = small for gestational age; UA = uterine artery 
De Vivo et al. found that the prediction rate of PlGF/sFlt-1 ratio is about $89 \%$ for PE [56]. As a single biochemical marker, PlGF has been shown to predict $53.5 \%$ of early onset $\mathrm{PE}$ at a false positive rate of $5 \%$ and $65 \%$ at a false positive rate of $10 \%$ in late first trimester [55]. PIGF value is also low with pregnancy complications associated with a dysfunctional placenta (SGA, preeclampsia or both) [44]. Several studies have found that low PlGF concentrations in first trimester are also predictive factor for SGA, even in the absence of preeclampsia $[40,42,47]$.

\section{Soluble Fms-like tyrosine kinase-1}

Most studies about the role sFlt1 in PE evaluation have shown that elevated second trimester sFlt1 predicts preeclampsia (Table V) [29,38,41,57-59]. sFlt1 is a better predictor for the early-onset type of preeclampsia, which has worse pregnancy outcomes when compare with the late onset type of preeclampsia.

As for sFlt1 measured in first trimester blood samples, there are discrepant findings. Levine et al. found elevated levels of circulating sFlt1 5 weeks prior to clinical preeclampsia, but detected no association with sFlt1 in first trimester [38]. In contrast, a large nested case-control study within a cohort of nearly 30,000 pregnant women in Norway showed that low sFlt1 in first trimester predicted early onset preeclampsia [41]. Kusanovic et al. also had confirmed that low sFlt1 in first trimester predicting preterm (as well as term) preeclampsia [43] and Erez et al. [42]. Although after adjusting for BMI, age and nulliparity, this significance had disappeared.

\section{Soluble endoglin}

Soluble endoglin (s-Eng) has been found elevated approximately 2-3 months before clinical presentation of the PE [60]. When, s-Eng used as first trimester screening marker, it shows conflicting results [42]. The prediction rate for early onset PE was $77.8 \%$ at a false positive rate of $5 \%$ (61) when s-Eng is used with Doppler ultrasound and PlGF.

\section{Cystatin C}

Cystatin $\mathrm{C}$ is a protease inhibitor and it has widely usage area by clinicians as a sensitive marker for renal function and for estimation of glomerular filtration rate. The maternal plasma level of cystatin $\mathrm{C}$

\begin{tabular}{|c|c|c|c|}
\hline Reference & $\mathrm{Pz}$ (n.) & Gestational week & Results \\
\hline Sibia [29] & 104 & $\begin{array}{l}12-20 \\
24-28\end{array}$ & $\begin{array}{l}\text { sFlt1 at week } 16 \text { does not predict PE. End of second trimester sFlt1 and } \\
\text { sFlt1/PIGF ratio predicts preterm delivered PE }\end{array}$ \\
\hline Levine [38] & 120 & $>13$ & $\begin{array}{l}\text { Elevated sFlt } 1 \text { in second trimester predicts } \mathrm{PE} \text { and is elevated as compared to } \\
\text { controls } 5 \text { weeks prior to clinical PE }\end{array}$ \\
\hline Vatten [41] & 344 & $\begin{array}{c}4-12 \\
19-27\end{array}$ & $\begin{array}{l}\text { Low sFlt1 in first trimester predicts early-onset PE. High sFlt1 second } \\
\text { trimester predicts early-onset PE. High increase in sFlt1 from first to second } \\
\text { trimester strongly predicts PE }\end{array}$ \\
\hline Moore [58] & 94 & $\begin{array}{l}22-26 \\
27-30 \\
31-35\end{array}$ & $\begin{array}{l}\text { Second trimester elevated sFlt1 predicts early-onset PE. Elevated sFlt1 } \\
\text { predictive for term PE only late in pregnancy (week 31-35). Elevated late } \\
\text { sFlt1 predicts all forms of PE }\end{array}$ \\
\hline Stephan [59] & 8 & 22 & Elevated sFlt1 prior to PE in high-risk population \\
\hline
\end{tabular}

Table V. Biochemical prediction of soluble Fms-like tyrosine kinase-1 (sFtl1) as marker of preeclampsia

$\mathrm{PE}=$ preeclampsia; $\mathrm{PIGF}=$ placental growth factor 
is increased in women with $\mathrm{PE}$ and authors had demonstrated that the level of cystatin $\mathrm{C}$ is a reliable diagnostic marker for PE $[62,63]$. Recently cystatin $\mathrm{C}$ has been suggested as a predictive first trimester marker for PE [64]. However, the low screening rate of the study, cystatin $\mathrm{C}$ is probably not clinically useful as a single marker [65]. Thilaganathan et al. showed that cystatin C could be useful in combination with other predictive markers [65].

\section{PTX3}

Pentraxin 3 (PTX3) is a secreted protein as part of an inflammatory immune response and is increased as an acute phase protein molecule like acute phase reactant [66]. Both with manifestations of PE as well before clinical symptoms, there is an increased secretion of PTX3 in the maternal circulation $[67,68]$.

\section{P-selectin}

P-selectin is a cell adhesion molecule, and plays a role in endothelial dysfunction. Placental ischemia and endothelial dysfunction are main components in the context of preeclampsia and as a result of these P-selectin levels found in high serum concentrations [69]. This situation mainly detectable in the first trimester of pregnancy $[67,68]$.

\section{IGFBP-1 and 3}

Both insulin-like growth factor binding proteins are the focus of the new researches. Both, in earlyand late- onset preeclampsia, IGFBP-1 is decreased in the first trimester. Such changes are detected by secretion of when we investigate the levels of the IGFBP-3, it elevates only in late-onset preeclampsia. In both cases, there is no correlation to a disturbed trophoblast invasion [70,71].

\section{Adiponectin}

Nanda et al. found that adiponectin levels increase in early PE but not in late PE and that there is no significant association between adiponectin and PAPP-A or uterine artery PI. Serum adiponectin did not improve the performance of screening for PE provided by a combination of the maternal factors, uterine artery PI and serum PAPP-A [72].

\section{Discussion and conclusions}

Preeclampsia is associated with significant morbidity and mortality for both mother and fetus. Most important objective for this disorder should be having chance of early diagnosis and develop an approach using biomarkers to detect, as early as possible, women at risk of developing preeclampsia with a greater performance than conventional methods. This situation offers a targeted manner, prophylactic interventions, specific surveillance and closer management. Although many different potential markers exist for preeclampsia, the reliability of these markers in predicting preeclampsia has been inconsistent between different studies. When we reviewed the studies about preeclampsia none of the biochemical markers has shown to be universally acceptable and reliable potentially predictive value for preeclampsia.

The appropriate biochemical marker for PE should give idea in the pathogenesis and be specific for the status of the disease. They also appear at the beginning of pregnancy or before the clinical manifestations of the disease with high sensitivity and specificity for early diagnosis and enough time for chance for the treatment. These tests must be easy and cheap to measure in maternal blood universal usage. Also they must correlate with the severity of the disease for exact diagnosis and using required treatment modalities. Cnossen et al. reviewed tests for predicting preeclampsia, performing a meta-analysis of 219 studies. At the end of the study, they found the accuracy of 27 tests for predicting preeclampsia, among these 
were 10 blood based biochemistry tests [73]. No test had a high level of both sensitivity and specificity greater than $90 \%$.

Several authors have studied that combination of markers improves test accuracy in predicting preeclampsia. Because of the complex structure of the PE, a combination of independent biomarkers, each reflecting a different part of the pathophysiology of the disease, should increase the likelihood to derive appropriate predictive methods [74,75]. Screening for Downs's syndrome in the first trimester is a good example where a combination of ultrasound scanning and biochemical markers are used. For instance, the combination of uterine artery Doppler pathological findings with altered biochemical markers in second trimester have shown better than use of the Doppler test or the factors alone for prediction of the PE [59,76-78]. Stepan et al. showed that combination of abnormal Doppler findings with sFlt1 increased the sensitivity of Doppler alone for preterm delivery from $67 \%$ to $83 \%$ and the specificity from $76 \%$ to $89 \%$ [59]. Crispi et al. found $90 \%$ sensitivity and $95 \%$ specificity for identifying early onset preeclampsia when using the combination of second trimester serum PlGF and uterine artery mean pulsatility index [77]. Stepan et al. also recently showed that using the combination of sFlt1 and sEng in second trimester was able to predict early-onset preeclampsia in women with abnormal uterine artery Doppler findings with $100 \%$ sensitivity and $93 \%$ specificity [77].

New technologic developments that may aid the search of new screening biological markers include gel-free proteomics with a mass-spectrometry approach that identify global protein changes in plasma. Blankley et al. showed elevation of several circulating proteins in pregnancies with preeclampsia as compared to normal pregnancies, including PAPP-A, endoglin and pregnancy-specific-beta-1-glycoprotein 1 . This situation is currently under investigation whether this proteomics approach can identify global protein differences also prior to disease [79]. Metabolomic products have also been suggested as a investigation modality for identifying new biomarkers for preeclampsia. Kenny et al. identified eight metabolomic products that with high sensitivity and specificity differentiated pregnancies with preeclampsia from control pregnancy blood [80].

Current researchers focus on the prediction of onset of preeclampsia so as to allow early management and improve the morbidity and mortality associated with this disease. The appropriate biochemical marker for PE should give idea in the pathogenesis and be specific for the status of the disease. As preeclampsia has a complex pathophysiology, the pursuit of a single biomarker that will predict all sorts of clinical situation of the disease, may prove difficult. Recent studies carried out in the direction of a combination of the biochemical and other markers. However, not yet been found fully appropriate marker. More extensive and appropriate studies should be done about it.

Future directions for research

Future studies should be undertaken focusing on finding new markers, or a combination of them, that will early predict the onset of preeclampsia.

\section{The review in brief}

Clinical question Describe biochemical markers suggested for both prediction and diagnosis of PE

Type of review Narrative

Conclusions and Although many different potential markers exist for preeclampsia, the reliability of these markers in limitations predicting preeclampsia has been inconsistent between different studies. Recent studies carried out in the direction of a combination of the biochemical and other markers 


\section{References}

1. Wagner SJ, Barac S, Garovic VD. Hypertensive pregnancy disorders: current concepts. J Clin Hypertens 2007; 9: 560-6; http://dx.doi.org/10.1111/j.1524-6175.2007.06695.x

2. Trupin LS, Simon LP, Eskenazi B. Change in paternity: a risk factor for preeclampsia in multiparas. Epidemiology 1996; 7: 240-4; http://dx.doi.org/10.1097/00001648-199605000-00004

3. Steinberg G, Khankin EV, Karumanchi KM. Angiogenic factors and preeclampsia. Thrombosis Research 2009; 123: S93-9; http://dx.doi.org/10.1016/S0049-3848(09)70020-9

4. Venkatesha $S$, Toporsian M, Lam C. et al. Soluble endoglin contributes to the pathogenesis of preeclampsia. Nature Medicine 2006; 12: 642-9; http://dx.doi.org/10.1038/nm1429

5. Roberts JM, Cooper DW. Pathogenesis and genetics of pre-eclampsia. The Lancet 2001; 357: 53-6; http://dx.doi.org/10.1016/S0140-6736(00)03577-7

6. Redman CW, Sargent IL. Latest advances in understanding preeclampsia. Science 2005; 308: 1592 4; http://dx.doi.org/10.1126/science.1111726

7. Saito S, Shiozaki A, Nakashima A, et al. The role of the immune system in preeclampsia. Mol Aspects Med 2007; 28: 192-9; http://dx.doi.org/10.1016/j.mam.2007.02.006

8. Redman CW, Sargent IL. Immunology of pre-eclampsia. Am J Reprod Immunol 2010; 63: 534-43; http://dx.doi.org/10.1111/j.1600-0897.2010.00831.x

9. Bayram M, Bostanc1 MS,Celtemen B, et al. Maternal Inflammatory Response in Severe Preeclamptic and Preeclamptic Pregnancies. J Clin Gynecol Obstet 2012; 1: 40-5

10. Chaouat G, Tranchot Diallo J, Volumenie JL, et al. Immune suppression and Th1/Th2 balance in pregnancy revisited: a (very) personal tribute to Tom Wegmann. Am J Reprod Immunol 1997; 37: 427-34; http://dx.doi.org/10.1111/j.1600-0897.1997.tb00255.x

11. Kalkunte S, Lai Z, Norris WE, et al. Novel approaches for mechanistic understanding and predicting preeclampsia. J Reprod Immunol 2009; 83: 134-8; http://dx.doi.org/10.1016/j.jri.2009.08.006

12. Westergaard JG, Teisner B, Grudzinskas JG. Serum PAPP-A in normal pregnancy: relationship to fetal and maternal characteristics. Arch Gynecol 1983; 233: 211e5

13. Kagan KO, Wright D, Valencia C, et al. Screening for trisomies 21,18 and 13 by maternal age, fetal nuchal translucency, fetal heart rate, free beta-hCG and pregnancy-associated plasma protein-A. Hum Reprod 2008; 23: 1968-75; http://dx.doi.org/10.1093/humrep/den224

14. Goetzinger KR, Singla A, Gerkowicz S, et al. Predicting the risk of pre-eclampsia between 11 and 13 weeks' gestation by combining maternal characteristics and serum analytes, PAPP-A and free beta-hCG. Prenat Diagn 2010; 30: 1138-42; http://dx.doi.org/10.1002/pd.2627

15. D'Anna R, Baviera G, Giordano D, et al. First trimester serum PAPP-A and NGAL in the prediction of late-onset pre-eclampsia. Prenat Diagn 2009; 29: 1066-8; http://dx.doi.org/10.1002/pd.2339

16. Ong CY, Liao AW, Spencer K, et al. First trimester maternal serum free beta human chorionic gonadotrophin and pregnancy associated plasma protein A as predictors of pregnancy complications. BJOG 2000; 107: 1265-70; http://dx.doi.org/10.1111/j.1471-0528.2000.tb11618.x

17. Smith GC, Stenhouse EJ, Crossley JA, et al. Early pregnancy levels of pregnancy-associated plasma protein A and the risk of intrauterine growth restriction, premature birth, preeclampsia, and stillbirth. J Clin Endocrinol Metab 2002; 87: 1762-7; http://dx.doi.org/10.1210/jc.87.4.1762

18. Bersinger NA, Odegard RA. Second- and third-trimester serum levels of placental proteins in preeclampsia and small-forgestational age pregnancies. Acta Obstet Gynecol Scand 2004; 83: 37-45; http://dx.doi.org/10.1111/j.1600-0412.2004.00277.x

19. Spencer K, Yu CK, Cowans NJ, et al. Prediction of pregnancy complications by first-trimester maternal serum PAPP-A and free beta-hCG and with second-trimester uterine artery Doppler. Prenat Diagn 2005; 25: 949-53; http://dx.doi.org/10.1002/pd.1251 
20. Spencer K, Cowans NJ, Nicolaides KH. Low levels of maternal serum PAPP-A in the first trimester and the risk of pre-eclampsia. Prenat Diagn 2008; 28: 7-10; http://dx.doi.org/10.1002/pd.1890

21. Dugoff L, Hobbins JC, Malone FD, et al. First-trimester maternal serum PAPP-A and free-beta subunit human chorionic gonadotropin concentrations and nuchal translucency are associated with obstetric complications: a population-based screening study (the FASTER Trial). Am J Obstet Gynecol 2004; 191: 1446-51; http://dx.doi.org/10.1016/j.ajog.2004.06.052

22. Canini S, Prefumo F, Pastorino D, et al. Association between birth weight and first-trimester free beta-human chorionic gonadotropin and pregnancy-associated plasma protein A. Fertil Steril 2008; 89: 174-8; http://dx.doi.org/10.1016/j.fertnstert.2007.02.024

23. Muttukrishna S, Knight PG, Groome NP, et al. Activin A and inhibin A as possible endocrine markers for preeclampsia. Lancet 1997; 349: 1285-8; http://dx.doi.org/10.1016/S0140-6736(96)09264-1

24. Salomon LJ, Benattar C, Audibert F, et al. Severe preeclampsia is associated with high inhibin A levels and normal leptin levels at 7-13 weeks into pregnancy. Am J Obstet Gynecol 2003; 189: 1517 22; http://dx.doi.org/10.1016/S0002-9378(03)00902-5

25. Roes EM, Gaytant MA, Thomas CM, et al. First trimester inhibin-A concentrations and later development of preeclampsia. Acta Obstet Gynecol Scand 2004; 83: 117; http://dx.doi.org/10.1111/ j.1600-0412.2004.00140.x

26. Diesch $\mathrm{CH}$, Holzgreve W, Hahn S, et al. Comparison of activin A and cell-free fetal DNA levels in maternal plasma from patients at high risk for preeclampsia. Prenat Diagn 2006; 26: 1267-70; http://dx.doi.org/10.1002/pd.1606

27. Zwahlen M, Gerber S, Bersinger NA. First trimester markers for preeclampsia: placental vs. non-placental protein serum levels. Gynecol Obstet Invest 2007; 63: 15-21; http://dx.doi. org/10.1159/000094672

28. Muttukrishna S, North RA, Morris J, et al. Serum inhibin A and activin A are elevated prior to the onset of pre-eclampsia. Hum Reprod 2000; 15: 1640-5; http://dx.doi.org/10.1093/ humrep/15.7.1640

29. Sibai BM, Koch MA, Freire S, et al. Serum inhibin A and angiogenic factor levels in pregnancies with previous preeclampsia and/or chronic hypertension: are they useful markers for prediction of subsequent preeclampsia? Am J Obstet Gynecol 2008; 199: 268-9; http://dx.doi.org/10.1016/j. ajog.2008.06.071

30. Spencer K, Yu CK, Savvidou M, et al. Prediction of pre-eclampsia by uterine artery Doppler ultrasonography and maternal serum pregnancy-associated plasma protein-A, free beta-human chorionic gonadotropin, activin A and inhibin A at $22+0$ to $24+6$ weeks' gestation. Ultrasound Obstet Gynecol 2006; 27: 658-63; http://dx.doi.org/10.1002/uog.2676

31. Than NG, Pick E, Bellyei S, et al. Functional analyses of placental protein 13/galectin-13. Eur J Biochem 2004; 271: 1065-78

32. Visegrady B, Than NG, Kilar F, et al. Homology modelling and molecular dynamics studies of human placental tissue protein 13 (galectin-13). Protein Eng 2001; 14: 875-80

33. Akolekar R, Syngelaki A, Beta J, et al. Maternal serum placental protein 13 at 11-13 weeks of gestation in preeclampsia. Prenat Diagn 2009; 29: 1103-8; http://dx.doi.org/10.1002/pd.2375

34. Khalil A, Cowans NJ, Spencer K, et al. First trimester markers for the prediction of pre-eclampsia in women with a-priori high risk. Ultrasound Obstet Gynecol 2010; 35: 671-9; http://dx.doi. org/10.1002/uog.7559

35. Nicolaides KH, Bindra R, Turan OM, et al. A novel approach to first-trimester screening for early pre-eclampsia combining serum PP-13 and Doppler ultrasound. Ultrasound Obstet Gynecol 2006; 27: $13-7$

36. Stamatopoulou A, Cowans NJ, Matwejew E, et al. Placental Protein-13 and pregnancy-associated plasma Protein-A as first trimester screening markers for hypertensive disorders and small for 
gestational age outcomes. Hypertens Pregnancy 2011; 30: 384-95; http://dx.doi.org/10.3109/1064 1955.2010.484081

37. Polliotti BM, Fry AG, Saller DN, et al. Second-trimester maternal serum placental growth factor and vascular endothelial growth factor for predicting severe, early onset preeclampsia. Obstet Gynecol 2003; 101: 1266-74; http://dx.doi.org/10.1016/S0029-7844(03)00338-7

38. Levine RJ, Maynard SE, Qian C, et al. Circulating angiogenic factors and the risk of preeclampsia. N Engl J Med 2004; 350: 672-83; http://dx.doi.org/10.1056/NEJMoa031884

39. Tidwell SC, Ho HN, Chiu WH, et al. Low maternal serum levels of placenta growth factor as an antecedent of clinical preeclampsia. Am J Obstet Gynecol 2001; 184: 1267-72; http://dx.doi. org/10.1067/mob.2001.113129

40. Thadhani R, Mutter WP, Wolf M, et al. First trimester placental growth factor and soluble fms-like tyrosine kinase 1 and risk for preeclampsia. J Clin Endocrinol Metab 2004; 89: 770-5; http://dx.doi. org/10.1210/jc.2003-031244

41. Vatten LJ, Eskild A, Nilsen TI, et al. Changes in circulating level of angiogenic factors from the first to second trimester as predictors of preeclampsia. Am J Obstet Gynecol 2007; 196: 239-46; http:// dx.doi.org/10.1016/j.ajog.2006.10.909

42. Erez O, Romero R, Espinoza J, et al. The change in concentrations of angiogenic and anti-angiogenic factors in maternal plasma between the first and second trimesters in risk assessment for the subsequent development of preeclampsia and small-for-gestational age. J Matern Fetal Neonatal Med 2008; 21: 279-87; http://dx.doi.org/10.1080/14767050802034545

43. Kusanovic JP, Romero R, Chaiworapongsa T, et al. A prospective cohort study of the value of maternal plasma concentrations of angiogenic and anti-angiogenic factors in early pregnancy and midtrimester in the identification of patients destined to develop preeclampsia. J Matern Fetal Neonatal Med 2009; 22: 1021-38; http://dx.doi.org/10.3109/14767050902994754

44. Taylor RN, Grimwood J, Taylor RS, et al. Longitudinal serum concentrations of placental growth factor: evidence for abnormal placental angiogenesis in pathologic pregnancies. Am J Obstet Gynecol 2003; 188: 177-82; http://dx.doi.org/10.1067/mob.2003.111

45. Ong CY, Liao AW, Cacho AM, et al. First trimester maternal serum levels of placenta growth factor as predictor of preeclampsia and fetal growth restriction. Obstet Gynecol 2001; 98: 608-11; http:// dx.doi.org/10.1016/S0029-7844(01)01528-9

46. Smith GC, Crossley JA, Aitken DA, et al. Circulating angiogenic factors in early pregnancy and the risk of preeclampsia, intrauterine growth restriction, spontaneous preterm birth, and stillbirth. Obstet Gynecol 2007; 109: 1316-24; http://dx.doi.org/10.1097/01.AOG.0000265804.09161.0d

47. Tjoa ML, van Vugt JM, Mulders MA, et al. Plasma placenta growth factor levels in midtrimester pregnancies. Obstet Gynecol 2001; 98: 600-7; http://dx.doi.org/10.1016/S0029-7844(01)01497-1

48. Su YN, Lee CN, Cheng WF, et al. Decreased maternal serum placenta growth factor in early second trimester and preeclampsia. Obstet Gynecol 2001; 97: 898-904; http://dx.doi.org/10.1016/ S0029-7844(01)01341-2

49. Chappell LC, Seed PT, Briley A, et al. A longitudinal study of biochemical variables in women at risk of preeclampsia. Am J Obstet Gynecol 2002; 187: 127-36; http://dx.doi.org/10.1067/ mob.2002.122969

50. Krauss T, Pauer HU, Augustin HG. Prospective analysis of placenta growth factor (PlGF) concentrations in the plasma of women with normal pregnancy and pregnancies complicated by preeclampsia. Hypertens Pregnancy 2004; 23: 101-11; http://dx.doi.org/10.1081/PRG-120028286

51. Kim SY, Ryu HM, Yang JH, et al. Increased sFlt-1 to PlGF ratio in women who subsequently develop preeclampsia. J Korean Med Sci 2007; 22: 873-7; http://dx.doi.org/10.3346/jkms.2007.22.5.873

52. Espinoza J, Romero R, Nien JK, et al. Identification of patients at risk for early onset and/or severe preeclampsia with the use of uterine artery Doppler velocimetry and placental growth factor. Am J Obstet Gynecol 2007; 196: 326.e1-13; http://dx.doi.org/10.1016/j.ajog.2006.11.002 
53. Akolekar R, de Cruz J, Foidart JM, Munaut C, Nicolaides KH. Maternal plasma soluble fms-like tyrosine kinase-1 and free vascular endothelial growth factor at 11 to 13 weeks of gestation in preeclampsia. Prenat Diagn 2010; 30: 191-7; http://dx.doi.org/10.1002/pd.2433

54. De Vivo A, Baviera G, Giordano D, Todarello G, Corrado F, D’Anna R. Endoglin, PlGF and sFlt1 as markers for predicting pre-eclampsia. Acta Obstet Gynecol Scand 2008; 87: 837-42; http:// dx.doi.org/10.1080/00016340802253759

55. Unal ER, Robinson CJ, Johnson DD, et al. Second-trimester angiogenic factors as biomarkers for future-onset preeclampsia. Am J Obstet Gynecol 2007; 197: 211-4; http://dx.doi.org/10.1016/j. ajog.2007.05.022

56. Romero R, Nien JK, Espinoza J, et al. A longitudinal study of angiogenic (placental growth factor) and antiangiogenic (soluble endoglin and soluble vascular endothelial growth factor receptor-1) factors in normal pregnancy and patients destined to develop preeclampsia and deliver a small for gestational age neonate. J Matern Fetal Neonatal Med 2008; 21: 9-23; http://dx.doi. org/10.1080/14767050701830480

57. Kim SY, Ryu HM, Yang JH, et al. Increased sFlt-1 to PlGF ratio in women who subsequently develop preeclampsia. J Korean Med Sci 2007; 22: 873-7; http://dx.doi.org/10.3346/jkms.2007.22.5.873

58. Moore Simas TA, Crawford SL, Solitro MJ, et al. Angiogenic factors for the prediction of preeclampsia in high-risk women. Am J Obstet Gynecol 2007; 197: 244-8; http://dx.doi.org/10.1016/j. ajog.2007.06.030

59. Stepan H, Geipel A, Schwarz F, et al. Circulatory soluble endoglin and its predictive value for preeclampsia in second-trimester pregnancies with abnormal uterine perfusion. Am J Obstet Gynecol 2008; 198: 175-6; http://dx.doi.org/10.1016/j.ajog.2007.08.052

60. Levine RJ, Lam C, Qian C, et al. Soluble endoglin and other circulating antiangiogenic factors in preeclampsia. N Engl J Med 2006; 355: 992-1005; http://dx.doi.org/10.1056/NEJMoa055352

61. Foidart JM, Munaut C, Chantraine F, et al. Maternal plasma soluble endoglin at 11-13 weeks' gestation in pre-eclampsia. Ultrasound Obstet Gynecol 2010; 35: 680-7; http://dx.doi.org/10.1002/uog.7621

62. Kristensen K, Wide-Swensson D, Schmidt C, et al. Cystatin C, beta-2-microglobulin and betatrace protein in pre-eclampsia. Acta Obstet Gynecol Scand 2007; 86: 921-6

63. Strevens H, Wide-Swensson D, Grubb A. Serum cystatin C is a better markerfor preeclampsia than serum creatinine or serum urate. Scand J Clin Lab Invest 2001; 61: 575-80

64. Thilaganathan B, Ralph E, Papageorghiou AT, et al. Raised maternal serum cystatin C: an early pregnancy marker for preeclampsia. Reprod Sci 2009; 16: 788-93; http://dx.doi. org/10.1177/1933719109336618

65. Thilaganathan B, Wormald B, Zanardini C, et al. Early-pregnancy multiple serum markers and secondtrimester uterine artery Doppler in predicting preeclampsia. Obstet Gynecol 2010; 115: 12338; http://dx.doi.org/10.1097/AOG.0b013e3181dd5137

66. Garlanda C, Bottazzi B, Bastone A, et al. Pentraxins at the crossroads between innate immunity, inflammation, matrix deposition, and female fertility. Annu Rev Immunol 2005; 23: 337-66; http:// dx.doi.org/10.1146/annurev.immunol.23.021704.115756

67. Akolekar R, Syngelaki A, Sarquis R, et al. Prediction of early, intermediate and late preeclampsia from maternal factors, biophysical and biochemical markers at 11-13 weeks. Prenat Diagn 2011; 31: 66-74; http://dx.doi.org/10.1002/pd.2660

68. Poon LC, Akolekar R, Lachmann R, et al. Hypertensive disorders in pregnancy: screening by biophysical and biochemical markers at 11-13 weeks. Ultrasound Obstet Gynecol 2010; 35: 662-70; http://dx.doi.org/10.1002/uog.7628

69. Granger JP, Alexander BT, Llinas MT, et al. Pathophysiology of hypertension during preeclampsia linking placental ischemia with endothelialdysfunction. Hypertension 2001; 38: 718-22; http:// dx.doi.org/10.1161/01.HYP.38.3.718 
70. Sifakis S, Akolekar R, Kappou D, et al. Maternal serum insulin-like growth factor-binding protein-1 (IGFBP-1) at 11-13 weeks in pre-eclampsia. Prenat Diagn 2011; 31: 196-201; http://dx.doi. org/10.1002/pd.2682

71. Sifakis S, Akolekar R, Kappou D, et al. Maternal serum insulin-like growth factor-binding protein-3 (IGFBP-3) at 11-13 weeks in pre-eclampsia. J Hum Hypertens 2012; 26: 253-8; http://dx.doi. org/10.1038/jhh.2011.16

72. Nanda S, Yu CK, Giurcaneanu L, et al. Maternal serum adiponectin at 11-13 weeks of gestation in preeclampsia. Fetal Diagn Ther 2011; 29: 208-15; http://dx.doi.org/10.1159/000322402

73. Cnossen JS, Ter RG, Mol BW, et al. Are tests for predicting pre-eclampsia good enough to make screening viable? A review of reviews and critical appraisal. Acta Obstet Gynecol Scand 2009; 88: 758-65; http://dx.doi.org/10.1080/00016340903008953

74. Giguère $\mathrm{Y}$, Charland $\mathrm{M}$, Bujold $\mathrm{E}$, et al. Combining biochemical and ultrasonographic markers in predicting preeclampsia: a systematic review. Clin Chem 2010; 56: 361-74; http://dx.doi. org/10.1373/clinchem.2009.134080

75. Cetin I, Huppertz B, Burton G, et al. Pregenesys pre-eclampsia markers consensus meeting: What do we require from markers, risk assessment and model systems to tailor preventive strategies? Placenta 2011; 32: S4-S16; http://dx.doi.org/10.1016/j.placenta.2010.11.022

76. Akolekar R, Zaragoza E, Poon LC, et al. Maternal serum placental growth factor at $11+0$ to $13+6$ weeks of gestation in the prediction of pre-eclampsia. Ultrasound Obstet Gynecol 2008; 32: 732-9; http://dx.doi.org/10.1002/uog.6244

77. Crispi F, Llurba E, Dominguez C, et al. Predictive value of angiogenic factors and uterine artery Doppler for early- versus late-onset pre-eclampsia and intrauterine growth restriction. Ultrasound Obstet Gynecol 2008; 31: 303-9; http://dx.doi.org/10.1002/uog.5184

78. Stepan H, Unversucht A, Wessel N, et al. Predictive value of maternal angiogenic factors in second trimester pregnancies with abnormal uterine perfusion. Hypertension 2007; 49: 818-24; http:// dx.doi.org/10.1161/01.HYP.0000258404.21552.a3

79. Blankley R, Gaskell S, Whetton A, et al. A proofof- principle gel-free proteomics strategy for the identification of predictive biomarkers for the onset of pre-eclampsia. BJOG 2009; 116: 1473-80; http://dx.doi.org/10.1111/j.1471-0528.2009.02283.x

80. Kenny LC, Broadhurst D, Brown M, et al. Detection and identification of novel metabolomic biomarkers in preeclampsia. Reprod Sci 2008; 15: 591-7; http://dx.doi.org/10.1177/1933719108316908 